Окрім розглянутих методів, що сприяють формуванню вокально-слухового самоконтролю, варто звернути увагу на такі:

- спів без музичного супроводу (a'cappella);

- спів вокальних вправ, вокалізів;

- оцінювання студентами один одного за заздалегідь накресленим планом.

Отже, застосування у класі постановки голосу розглянутих методів і прийомів, а також дотримання спеціальних правил, які допомагають зняти зовнішні і внутрішні голосові «затиски», на нашу думку, можуть сприяти формуванню вокально-слухового самоконтролю, який є важливим компонентом фахової підготовки студентів у вищих навчальних закладах мистецького спрямування. Перспективи подальших пошуків у напрямку дослідження полягають у розробленні змісту методичних рекомендацій щодо формування компонентів вокально-слухового самоконтролю у майбутніх учителів музичного мистецтва.

\title{
Література
}

1. Дмитриев Л. Б. Основы вокальной методики / Леонид Борисович Дмитриев. Москва : Музыка, 1968. - 675 с. 2. Донец-Тессейр М. Э. Опыт воспитания сопрано / М. Э. Донец-Тессейр // Вопросы вокальной педагогики : [сб. статей]. - Москва : Музгиз, 1967. - № 3. - С. 120-133. 2. Лемешев С. Я. Путь к искусству / Сергей Яковлевич Лемешев. - [3-е изд.]. - Москва : Искусство, 1982. - 280 с. 3. Люш Д. Развитие и сохранение певческого голоса / Д. Люш. - Київ : Музычна Украина, 1988. - 145 с. 4. Малышева Н. М. О работе певца над голосом / Н. М. Малышева // Вопросы вокальной педагогіки : [сб. статей]. Москва : Музгиз, 1962. - № 1. - С. 50-76. 5. Морозов В. П. Эмоциональный слух человека / В. П. Морозов // Эволюционная биохимия и физиология. - 1985. - Т. 21. - С. 568-577. 6. Павлова М. А. Формирование вокально-слухового самоконтроля у студентов музыкально-педагогического факультета на занятиях по постановке голоса: автореф. дис. на соискание ученой степени канд. пед. наук. : спец. 13.00.02 / Павлова Мария Александровна. Москва, 2002. - 22 с. 7. Стулова Г. П. Дидактические основы обучения пению : [учеб. пособие] / Галина Павловна Стулова; под ред. В. В. Мерцалова. - Москва : МГПИ, 1988. $68 \mathrm{c}$.

Микола Крижановський, Олександр Фурман

\section{МЕТОДИКА ФОРМОТВОРЧОГО ПРОЦЕСУ НА ЗАНЯТТЯХ ІЗ ДПМ СПЕЦАЛЬНОСТІ «ТЕХНОЛОГІЧНА ОСВІТА»}

Крижановський М. М., Фурман О. І. Методика формотворчого процесу на заняттях із ДПМ спеціальності «Технологічна освіта».

У статті розглядається проблема методики створення декоративного образу на заняттях 3 декоративно-прикладного мистецтва спеціальності «Технологічна освіта». Показано, що створення студентами - майбутніми вчителями технологій і креслення творів декоративно-прикладного мистецтва - суттєво залежить від методично правильного формотворчого процесу.

Ключові слова: декоративність, стилізація, методика, ескіз, композиція, малюнок, пластика.

Крижановский М. М., Фурман А. И. Методика формообразующего процесса на 
занятиях по ДПИ специальности «Технологическое образование».

В статье рассматривается проблема методики создания декоративного образа на занятиях по декоративно-прикладному искусству специальности «Технологическое образование». Показано, что создание студентами - будущими учителями технологий и черчения произведений декоративно-прикладного искусства существенно зависит от методически правильного формообразовательного процесса.

Ключевые слова: декоративность, стилизация, методика, эскиз, композиция, рисунок, пластика.

Kryzhanovskyy M. M, Furman A. I. Methods of technique creative process at the lessons of decorative and applied arts for the speciality "Engineering".

The article deals with problem of methods for creating ornamental image at the lessons of decorative and applied arts for the speciality engineering and drawing. It is shown that creation of decorative and applied arts works by the future teachers of engineering depends on technically appropriate creative process.

Key words: decorative effect, stylization, a technique, the sketch, a composition, drawing, a plasticity.

Реформування вітчизняної системи вищої педагогічної освіти на початку третього тисячоліття згідно 3 Болонською декларацією $\epsilon$ нагальною потребою формування особистості вчителя-технолога, який працює в галузі декоративно-прикладного мистецтва створення умов для підвищення його професійного рівня особливо тепер, коли підвищення культурологічного та естетичного світогляду людей, коли люди хочуть, щоб краса оточувала їх усюди, коли сфера застосування прикладного мистецтва поширюється.

Актуальність такої структури виховання ставить нові завдання до навчального процесу у вищій школі, висуває особливі вимоги до ефективної самореалізації майбутніх учителів праці, віднайденні педагогічних технологій, методів i засобів вивчення декоративно-прикладного мистецтва, що об'єднує художній початок 3 ужитковим, утворюючого предмети, практично необхідні і водночас красиві.

На наш погляд, одним із можливих напрямків розв'язання цих задач прогресивного гуманістичного напрямку декоративно-прикладного мистецтва полягає у розв'язанні проблем у методиці формотворчого процесу, що грунтується на глибокому вивченні декоративного малювання, ліплення та роботі з матеріалом.

Робота виконана в контексті програм НДР Криворізького педагогічного інституту.

У декоративно прикладному мистецтві важливе місце займає процес створення витворів декоративно-прикладного мистецтва. У методичній та професійній літературі 3 декоративно-прикладного мистецтва, психології (Ю. Арбат, Р. Арнхейм, Г. Громов, Н. Боголюбов, І Зарецкий, В. Кузин, І. Стін, А. Хворостов, Т. Шакалова, П. Якобсон) значну увагу приділяють цій проблемі. Але, на наш погляд, недостатньо розкривається методика формотворчого процесу, починаючи від створення ескізу і завершуючи виконанням роботи в матеріалі, яка суттєво впливає на розвиток професійних умінь у студентів- майбутніх учителів технологій і креслення на заняттях з ДПМ.

Mema cmammi - розглянути методику формування у студентів - майбутніх учителів технологій i креслення професійних умінь методично правильно створювати твори декоративно-прикладного мистецтва на заняттях з ДПМ.

Декоративно-прикладне мистецтво виникло в результаті бажання людини прикрасити 
свій побут, виразити своє ставлення до краси і сягає своїм корінням у глибини народної творчості. «Декоративно-прикладне мистецтво - це широка галузь мистецтва, яка слугує художньому формуванню матеріального середовища, створеного людиною, допомагає впровадженню в нього естетичного і ідейно-образного початку...» [6]. Протягом тисячоліть люди робили відбір не тільки форми з їі ужитковими функціями (прямим призначенням у використанні), але і їі декоративності.

Декоративність - це художнє оздоблення зовнішнього архітектурного спорудження, внутрішнього житла, предметів побуту й охоплює такі жанри, як: декоративні розписи, декоративна скульптура, мозаїка, вітражі, розпис і різьблення на різних матеріалах, художнє лиття з металу, чеканка, кераміка, карбування, килимарство, декоративні тканини тощо.

Декоративно-прикладне мистецтво об’єднує в собі формотворчий процес та образотворчі мотиви й орнаменти (візерунки). Під час створення мережива, килимів, вишивок, візерункового ткацтва, вітражів орнамент з'являється разом 3 формою i матеріалом, а під час формотворчого процесу дотримується основна вимога - синтез архітектури, скульптури, живопису та графіки.

Особливістю декоративно-ужиткового мистецтва, на відміну від інших видів мистецтва, є його стилістичність, тобто відсутність у зображенні прямої подібності 3 реальними предметами чи їх формами, які взяті за основу формотворчого процесу, а також ще одна особливість - поєднання ужиткових та естетичних функцій, біфункціональність аналізованого жанру мистецтва. Художньо-естетична особливість - досягнення синтезу матеріалу, форми, конструкції, композиційної гармонії та декору, ужиткова необхідність застосування твору в побуті.

Ми вважаємо, що проблеми щодо створення творів декоративно-вжиткового характеру на заняттях 3 декоративно-прикладного мистецтва спеціальності технологій i креслення мають місце, тому що методика формотворчого процесу недостатньо розроблена. Методика побудови витвору декоративно-прикладного мистецтва складається із розроблення ескізної частини твору, знаходженні композиції, декоративного малювання, декоративного живопису, декоративної скульптури та виконання твору в матеріалі. «Процес створення декоративних творів може бути успішним лише тоді, коли учень з самого початку уявляє собі кінцевий результат, який необхідно досягти. Тобто у процесі створення твору із дерева i металу учень планує свої дії. Тому що не зробивши попередньої операції, не можна перейти до наступної...» [5].

Ескізна частина передбачає розроблення форескіза, який може бути виконаний графічно, живописно або пластично. Форескіз стилізований і будується згідно з загальними законами, правилами та прийомами композиції, законами «рами». Форескіз виконується для того, щоб на самому початку процесу формотворення побачити декоративний образ у кінцевому результаті, виконаному в матеріалі. На наступному етапі ескізи виконуються більшого розміру, для детальнішого пророблення твору, конкретизації композиційного рішення і слугують прототипом для картонів, які виконуються в натуральну величину і $\epsilon$ перехідним етапом між ескізною частиною й етапом виконання декоративного образу в матеріалі. Картони виконуються, як правило, графічними засобами для графіки та скульптури, а для живопису-живописними.

У процесі виконання ескізів великого значення набуває виразність лінії силуетів чи окремої частини форми іiі спрощений стилізований символ. Незважаючи на лаконізм та умовність, малюнок будується так, щоб виникало уявлення про предмет, близький до живої 
природи. Мотивами формотворення для студентів можуть бути сюжети із навколишнього середовища, витвори мистецтва, музичні твори, художні й декоративні можливості матеріалу (наприклад, «коренепластика»).

Специфіка побудови ескізів залежить від матеріалу (залізо, дерево, камінь, кераміка, скло тощо) і впливає на характер малюнку й особливості композиції. Чіткий і виразний силует, узагальненість, схематичність форми, перебільшення найбільш характерних і суттєвих ознак предметів і явищ, відмова від другорядної деталізації, лаконізм і простота властиві для малюнку в декоративних композиціях.

Під час розроблення ескізів декоративно-прикладного характеру необхідно враховувати розміри і форму предмета, ступінь плотності наповнення форми, фактуру і текстуру матеріалу, зводячи процес ескізного формотворення до композиційної єдності завдяки законам композиції (пропорціям, масштабу, ритму, контрасту, нюансу тощо) та поєднуючи у проектуванні предметну (площинну), об'ємну і глибинно-просторову композиції. Ескізна частина формотворчого процесу побудови декоративного образу базується на знаннях законів композиції й законів «рами». Ці процеси взаємопов’язані.

Композиції в декоративно-прикладному мистецтві властивий визначений характер, який розкриває на площині своєрідну завершену форму. Узагальнення, спрощення, трансформація природних форм у декоративні образи є досить складною задачею для студентів, яким необхідно передати зображення площинно, виразними масами і плямами, у ритмічній побудові.

Об'єктивні закономірності закладають основи теорії композиції декоративноприкладного мистецтва. Де головне місце належить тектоніці (від грец. ictonikos, що означає «стосовний до будівництва»). Загальна система закономірностей - це єдність цілого і частин вказує на те, що будь-яка форма складається із частин. Ритм означає чергування декоративних елементів у динамічному чи статичному образі, виявляючи його симетрію чи асиметрію. Характер ритму створює кількість елементів і залежить від повторень світлих і темних плям, а також від проміжків між формами і їхніми напрямками. Закон пропорціїрозкриває пропорційну залежність цілого і частини, встановлює гармонію пропорційності декоративних елементів. Закономірність виділення головного в цілому відокремлює головне у формі від другорядного. Контраст у декоративній композиції протиставляє тонові, лінійні, колірні, об’ємні протилежності, збагачуючи форму виробу. Архітектоніка вказує на цілеспрямованість форми.

Декоративний малюнок має велике розходження із малюванням 3 натури. Коли 3 натури створюється образ, то природні форми зображуються в різних ракурсах із застосуванням тонових відношень, кольорових відтінків, лінійної та повітряної перспективи, тоді як у декоративному малюванні, як правило, відсутня тримірність і зображення будується на двомірній площині, форми та об'єми показуються у вигляді визначеного візерункового мотиву, узагальнено за допомогою умовних прийомів. «Художньо-виразна і технічна різновидність витворів декоративного мистецтва характеризована фронтальністю композиції, надзвичайно велика...» [4].

Процес декоративного малювання $\epsilon$ результатом віднайденого узгодження між сприйняттям навколишнього середовища й декоративного зображення дійсності. Композиційне розташування мотиву візерунку в колі, квадраті, смузі тощо розкриває сутність орнаменту який $\epsilon$ вираженням різних відчуттів і настроїв людини.

Елементи орнаменту розділяються на квадрати, прямокутники, трикутники, 
багатокутники, кола, овали тощо. Кожна геометрична форма символізує ті чи інші природні форми та явища, виражаючи психологію людських почуттів. Наприклад, квадрат створює враження спокою, прямокутник - відчуття тісноти, напруженості. Плавність, стрімкість, порив, різкість ритму в зображенні відбувається за рахунок зміни положення елементів візерунку.

Досягнення ліричності, м'якості, напруги або занепокоєння відбувається зміною плавності контурів або чергуванням різних положень основної деталі декору та її елементів, за рахунок спрощення, стилізації елементів композиції, природні форми перетворюються на декоративні образи, створюючи певний характер декоративного малюнку й особливий лад мотиву орнаменту чи декоративної форми.

Психологія формотворення узагальненого декоративного образу відображає психолого-фізіологічний процес абстрагування від низки часткових дрібничок. Перенасиченість деталей у формі заважає цілісному іiі сприйняттю, а також утрудняє побудову нових, більш оригінальних декоративних образів. Спрощення, стилізація, виділення їх у новому образі - напрямок, яким повинне рухатись декоративне малювання.

Декоративний живопис поділяється на сюжетний та орнаментальний i може застосовуватися як в екстер'єрі, так і в інтер'єрі. Конструктивні елементи (колони, стовпи, арки тощо) акцентувалися орнаментальним розписом, а поверхні стін прикрашали як сюжетним, так і візерунковим живописом виконаним у техніці олійного i клейового живопису, фрески, гризайлі (застосовувалася для прикраси палацових інтер'єрів, імітуючи скульптурні рельєфи), енкаустики (фарби, вплавлені в гарячий розтоплений віск, дозволяли створити рельєфну фактуру), вазопису (розпис керамічного посуду).

Декоративний живопис не прагне точно копіювати реалістичні форми, а відбирає найважливіше, істотне, відкидає непотрібні деталі, щось стилізує, скорочує, виділяє, підкреслює, перебільшує - створює нову декоративну форму.

Декоративна скульптура (лат. skulptura від sclupo- висікаю, вирізую), ліплення, пластика (грец. plastike, від plasso-ліплю), вид просторово-статичного мистецтва, заснованого на принципі тримірності, об'ємного зображення предмету. Об'єктом зображення в скульптурі є люди, тварини, птиці, риби, плазуни тощо. Виразними засобами цього виду мистецтва $є$ силует та різноманітність і краса матеріалу, через який сприймаємо динамічність чи статику композиції і виразність силуету. Пластика-гармонічне поєднання об'ємних форм, площин, пропорцій у ритмічному поєднанні вагових мас, що є наступним засобом впливом на глядача. Скульптура може передавати думку, почуття, стан i настрій людини. «...скульптура передає уявлення про ідеал людини, не просто відображає конкретний образ людей, але і в формі пластичних образів утверджує ідеал, учить ідеалу, розкриває людську гідність народу, передає духовний стан цілої епохи» [4].

Декоративна скульптура поділяється на два основні різновиди: круглу скульптуру та рельєф; монументально-декоративну, станкову і скульптуру малих форм. Монументальнодекоративна скульптура відіграє роль доповнення та збагачення виразності архітектурних образів новими відтінками. Величність і довговічність форм розраховані на конкретне архітектурне чи природно-просторове оточення із розв'язанням великих ідейно-образних задач. Станкова скульптура призначена для виставок, музеїв, житлових інтер'єрів і має більш інтимний характер. Для неї характерний інтерес до внутрішнього світу людини. Скульптура малих форм призначена переважно для житлових інтер'єрів. Техніка скульптури залежить від природних особливостей і способів оброблення. Глина, віск, пластилін служать для ліпки. Формовка та відливання із гіпсу $є$ перехідним етапом між м'яким i твердим

Педагогіка вищої та середної школи. - 2015. - Вип. 45 
матеріалом. Тверді матеріали (камінь, дерево, кістка) обробляються металевим інструментом шляхом різьблення чи рубання. Матеріали, які можуть набувати рідкого стану, служать для відливання декоративної скульптури з металу, бетону, пластмаси за допомогою спеціально виготовлених форм.

Декоративна скульптура відіграє важливу роль у покращенні нашого довкілля. Ці твори мистецтва сприймаються як єдине ціле в поєднанні скульптури в нашому інтер'єрі чи в злитті їі з нашим довкіллям. Сприйняття чи несприйняття людиною твору декоративного мистецтва залежить від композиційного вирішення декоративної композиції.

У процесі художнього оброблення матеріалів під час розроблення композиції декоративного характеру необхідно переключитися від знань та вмінь глибиннопросторового вирішення площини і перейти до відтворення предметного світу мовою декоративно-прикладного мистецтва. Побудова узагальненого декоративного образу залежить від процесу стилізації форми. Психолог Є. Ігнатьєв писав: «Велика кількість деталей у приватних образах заважає створенню образу із психологічної точки зору, $є$ процесом абстрагування від цілої низки часткових дрібниць нового оригінального образу. Процес виділення найбільш загальних ознак в часткових образах і об'єднання цих ознак у новому образі - ось цей шлях, який проходить уява; засоби виробництва (чекан, різець, молоток) і нова техніка виконання (різьблення, чеканка, на початковій стадії розвитку ... але як тільки зрозуміло саму загальну сутність образу, він потребує насичення деталями» [2].

Такі матеріали, як залізо, дерево, камінь, потребують інших виразних засобів формотворення на відміну від образотворчого процесу, в основі якого лежать реалістичні образи. Функціонуючи поряд, декоративно-прикладне та образотворче мистецтво мають свої особливості, задачі, свою образну мову і задача педагога сформувати у студентів вміння щодо створення красивих, ритмічних, емоційно насичених ескізів для роботи з тим чи іншим матеріалом (деревом, металом тощо).

Основою роботи в декоративному обробленні виробів є красиві, ритмічні й емоційно насичені орнаментальні побудови, як наслідок правильного методичного процесу декоративного формотворення, складниками якого є процеси створення ескізу на основі знань законів композиції за допомогою декоративного малювання, живопису і скульптури.

У роботі над декоративним образом важливе місце посідає знання матеріалу і техніка його виконання інструментами й технологія виготовлення. Водночас створення образу розпочинається із розроблення ескізу майбутнього твору, вирішенням його композиції, декоративним малюванням, живописом, ліпленням. Вивчення студентами - майбутніми учителями праці методики формотворчого процесу створення декоративних композицій допоможе їм правильно, професійно підходити до вивчення й побудови декоративного образу на заняттях декоративно-прикладного мистецтва спеціальності «Технологічна освіта».

\section{Література}

1. Боголюбов Н. С. Лепка на занятиях в школьном кружке / Н. С. Боголюбов. Москва : Просвещение, 1979. - 123 с. 2. Игнатьев Е. И. Психология изобразительной деятельности детей / Е. И. Игнатьев. - Москва : 1961. - 165 с. З. Кузин В. С. Психологопедагогические основы детского изобразительного творчества / В. С. Кузин // Творчество юных : [сборник]. - Москва : Просвещение, 1972. - 256 с. 4. Основы декоративного искусства в школе / под редакцией Б. В. Нешумова и Е. Д. Щедрина. - Москва : Просвещение, 1981. - 98 с. 5. Хворостов А. С. Декоративно-прикладное искусство в школе / А. С. Хворостов. - Москва: Просвещение, 1981. - 175 с. б. Хворостов А. С. Чеканка. 
Инкрустация. Резьба по дереву / А. С. Хворостов. - Москва : Просвещение, 1985. - 176 с. 7. Шорохов Е. В. Основы композиции / Е. В. Шорохов. - Москва : Просвещение, 1979. $223 \mathrm{c}$.

УДК [378:37.011.3-051]:5

Василь Кушнір

\section{ДО ПРОБЛЕМИ РОЗВИТКУ МЕТОДОЛОГІЧНОЇ КУЛЬТУРИ МАЙБУТНІХ УЧИТЕЛІВ ПРИРОДНИЧИХ ДИСЦИПЛІН У ПРОЦЕСІ ПРОФЕСІЙНОЇ ПІДГОТОВКИ: ВІДГУК НА МОНОГРАФІЧНЕ ДОСЛІДЖЕННЯ}

Кушнір В. А. До проблеми розвитку методологічної культури майбутніх учителів природничих дисциплін у процесі професійної підготовки: відгук на монографічне дослідження.

У статті розкриваються основні ідеї, наукові підходи, принципи щодо визначення суті й змісту методологічної культури вчителя природничих дисциплін і чинників іiї розвитку в системі професійної підготовки, на підгрунті аналізу монографічного дослідження О. О. Лаврентьєвої.

Ключові слова: методологічна культура вчителя, професійна підготовка вчителя, педагогічні умови, моніторинг процесу розвитку методологічної культури вчителя.

Кушнир В. А. О проблеме развития методологической культуры будущих учителей естественнонаучных дисциплин в процессе профессиональной подготовки: отзыв на монографическое исследование.

В статье раскрываются основные идеи, научные подходы, принципы относительно определения сути и содержания методологической культуры учителя естественнонаучных дисциплин и факторов ее развития в системе профессиональной подготовки на основе анализа монографического исследования Е. А. Лаврентьевой.

Ключевые слова: методологическая культура учителя, профессиональная подготовка учителя, педагогические условия, мониторинг процесса развития методологической культуры учителя.

Kushnir V. A. Concerning the problem of method competence of future teachers in natural sciences in the course of their professional training: review of monographic research.

The main ideas, scientific approaches, the principles concerning the definition of the essence and the content of method competence of teachers in natural sciences are revealed. The factors of method competence development in the course of professional training are considered on the analysis of monographic research of O. O. Lavrentieva.

Key words: method competence of a teacher, teacher's training, pedagogical conditions, monitoring of the teacher's method competence development.

Сучасному вчителю потрібні надпредметні знання високого рівня сформованості, які надали б можливість розв'язувати міжпредметно-системно-інтегративні проблеми, аналізувати й оцінювати нові педагогічні розробки й визначати їх місце у створеній методичній системі, розробляти власні підходи, методики, прийоми використання сучасних засобів навчання, передовсім інформаційно-комунікаційних технологій, визначати зміст власної методичної системи. Тому актуальність монографічного дослідження 